Review

\title{
Immunomodulatory Function of the Tumor Suppressor p53 in Host Immune Response and the Tumor Microenvironment
}

\author{
Yan Cui * and Gang Guo \\ Department of Biochemistry and Molecular Biology, Cancer Immunology, Inflammation \& Tolerance Program, \\ Georgia Cancer Center, Augusta University, Augusta, GA 30912, USA; gguo@augusta.edu \\ * Correspondence: ycui@augusta.edu; Tel.: +1-706-723-4153
}

Academic Editor: Tomoo Iwakuma

Received: 3 October 2016; Accepted: 10 November 2016; Published: 19 November 2016

\begin{abstract}
The tumor suppressor $p 53$ is the most frequently mutated gene in human cancers. Most of the mutations are missense leading to loss of p53 function in inducing apoptosis and senescence. In addition to these autonomous effects of $p 53$ inactivation/dysfunction on tumorigenesis, compelling evidence suggests that $p 53$ mutation/inactivation also leads to gain-of-function or activation of non-autonomous pathways, which either directly or indirectly promote tumorigenesis. Experimental and clinical results suggest that $p 53$ dysfunction fuels pro-tumor inflammation and serves as an immunological gain-of-function driver of tumorigenesis via skewing immune landscape of the tumor microenvironment (TME). It is now increasingly appreciated that $p 53$ dysfunction in various cellular compartments of the TME leads to immunosuppression and immune evasion. Although our understanding of the cellular and molecular processes that link p53 activity to host immune regulation is still incomplete, it is clear that activating/reactivating the p53 pathway in the TME also represents a compelling immunological strategy to reverse immunosuppression and enhance antitumor immunity. Here, we review our current understanding of the potential cellular and molecular mechanisms by which p53 participates in immune regulation and discuss how targeting the p53 pathway can be exploited to alter the immunological landscape of tumors for maximizing therapeutic outcome.
\end{abstract}

Keywords: tumor suppressor p53; 553 inactivation; tumor microenvironment; immune suppression; inflammation; innate immunity; adaptive antitumor immunity; immunotherapy

\section{Introduction}

The tumor suppressor p53, as a crucial transcription factor controlling the life and death of cells, has been known to prevent tumorigenesis via inducing apoptosis and senescence [1-4]. During the past decade, compelling evidence revealed that p53, as a master transcription factor and a crucial sensor of stress, participates in the regulation of a plethora of physiological processes throughout the entire lifespan of the organism, including stem cell state, development, tissue homeostasis, metabolism, and aging [5-9]. Thus, it is not surprising that $p 53$ dysfunction is linked to dysregulation of stem cell homeostasis, metabolism, autophagy, angiogenesis, migration, and invasion [6,10-12], all of which are linked to the hallmarks of cancer [13,14]. Similarly, experimental and clinical observations also suggest that environmentally induced damage and genetic instability are associated with $p 53$ dysfunction and inflammation [15-17]. Because chronic inflammation is a hallmark and a driver of cancer [13,18,19], it is plausible that $p 53$ dysfunction also contributes immunologically to tumorigenesis and tumor progression by altering host immune responses.

Historically, especially within the first 20 years of p53 research, the connection of p53 with host immune response and regulation had been mostly limited to employing fragments of p53 protein as 
tumor-associated antigens (TAAs) for tumor vaccines [20-22] because many forms of p53 mutation stabilize the p53 protein, resulting in elevated p53 level in tumors $[1,3,23,24]$. Recently, our studies and those of others have shown that $p 53$ inactivation/dysfunction alters the immune landscape of the tumor microenvironment (TME) towards pro-tumor inflammation [25-28], whereas p53 reactivation or restoration changes the milieu of TME to promote antitumor immunity [29-31]. It has been increasingly appreciated that 553 activity potentially regulates host immune function and modulates the immunological landscape of the TME. However, our comprehension of the cellular and molecular mechanisms through which p53 activity regulates host immune response and immune surveillance to tumors is still limited. Here, we review p53-related publications with specific focus on the implication of p53 activity and/or $p 53$ dysfunction in the host immune response and immunological aspects of tumorigenesis, respectively. We also discuss the potential novel strategies of targeting the p53 pathway for immunotherapy application to improve therapeutic outcome based on existing literature and our unpublished observations.

\section{Trp53 Dysfunction and Inflammation-The Non-Canonical and Non-Cell Autonomous Mechanism of Tumorigenesis}

It is indisputable that p53 activation-induced apoptosis and senescence is a crucial mechanism of tumor suppression, the so-called autonomous mechanism. Recently, compelling evidence demonstrates that p53 also suppresses tumorigenesis via changing the function and milieu of the transformed cells, which is regarded as the non-cell autonomous mechanism of tumor suppression [32,33]. One such non-cell autonomous mechanism that has been increasingly appreciated is the promotion of chronic inflammation.

It is important to be reminded that, in general, host immune response is an essential defense mechanism against pathogens and/or other environmental stress via an acute surge of innate immune cells, including monocytes, macrophages, dendritic cells (DCs), and natural killer (NK) cells, followed by activation of adaptive immune cells, including $\mathrm{T}$ and $\mathrm{B}$ cells, and release of effector cytokines and chemokines. The timely termination of activated immune effector cells and cytokines/chemokines when the potential threats are well controlled is as important as the rapid immune activation. Chronic inflammation, on the other hand, differs from the protective acute immune activation in that the unresolved pathogenic stimuli or endogenous stress lead to continued stimulation and recruitment of innate and adaptive immune cells, as well as constant release of pro-inflammatory cytokines/chemokines, all of which skew the milieu towards low-grade persistent inflammation in favor of tissue remodeling/wound healing and suppression of productive immunity. Therefore, chronic inflammation, as one of the hallmarks of cancer, compromises the proper balance of productive immune function and provides a favorable microenvironment for tumor initiation, progression, and metastases [13,16,18,19,34-36].

\subsection{Cellular Components of the Tumor Microenvironment Involved in p53 Dysfunction-Induced Chronic Inflammation}

Accumulating evidence suggests that tumor progression and metastases are markedly affected by the molecular and cellular constituents surrounding and within the tumor parenchyma, the so-called tumor microenvironment (TME) [37-39]. The TME is a highly complex functional ecosystem of tumor and other cellular and molecular components. The cellular constituents of the TME consist of stromal cells (cancer-associated fibroblasts-CAFs, blood, and lymphatic endothelial cells), tumor-infiltrating lymphocytes (T cells, B cells, and NK cells), and myeloid populations (DCs, macrophages, and myeloid-derived suppressor cells) (Figure 1). Many of the tumor-infiltrating immune cells possess immune suppressive function, such as regulatory T cells (Treg), myeloid-derived suppressor cells (MDSC), and type 2 macrophages (M2), which all actively sustain pro-tumor inflammation and immunosuppression [38-41]. The molecular constituents of the TME consist of extracellular matrix, cytokines and chemokines, and soluble immunosuppressive molecules. All these cellular and 
molecular components coordinately dictate the immunological landscape of the TME that promotes tumor initiation, progression, and metastasis by creating a chronically inflamed milieu that also protects tumor from immune surveillance and immune destruction $[35,42,43]$.

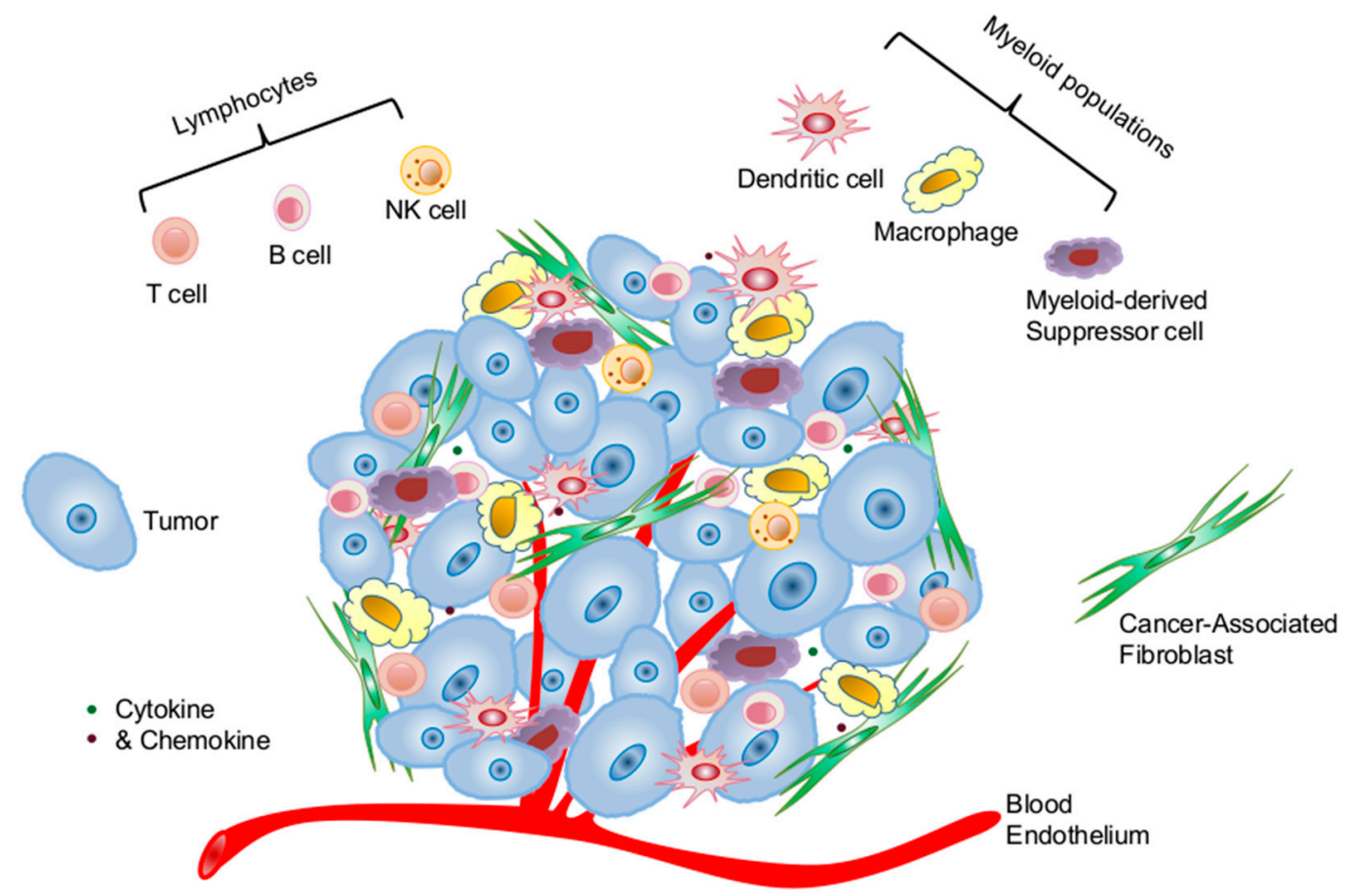

Figure 1. Cellular constituents of the tumor microenvironment that shape tumor immunological landscape. The tumor microenvironment consists of complex cellular and molecular and constituents. The cellular constituents consist of immune cells of hematopoietic origin and stromal cells of non-hematopoietic origin. The immune cell compartment comprises tumor-infiltrating lymphocytes of T, B, and natural killer cells and tumor-associated myeloid populations of dendritic cells, macrophages, and myeloid-derived suppressor cells. The stromal compartment consists of cancer-associated fibroblasts and endothelial cells of the lymphatic and blood vasculature. Trp53 inactivation has been observed in some of the cellular subpopulations of the tumor microenvironment, which compromises the proper balance of host immunity by promoting chronic inflammation and tumor progression.

\subsubsection{Cancer Cells of Epithelial Origin}

p53 mutations occur most frequently in solid tumors, i.e., cells of epithelial origin $[1,23,24]$. Although mutation frequency varies among different tumor types, $p 53$ mutations occur at a very high frequency in inflammation-associated cancers, such as colon, lung, pancreatic, and ovarian cancers $[15,16,44]$. This correlation between p53 mutation and inflammation does not explicate the cause-effect relationship. However, early clinical reports of highly elevated p53 activity in pathological tissues of autoimmune diseases, including rheumatoid arthritis (RA) [45,46], ulcerative colitis (UC) [15], and Sjögren's syndrome (SS) [47], indeed tend to suggest that p53 is a sensor of inflammatory stress [48]. Subsequent clinical studies illustrated that increased p53 expression in the inflamed tissues is associated with somatic dominant-negative $p 53$ mutations $[15,45,47]$. Together, these data imply that inflammation-induced p53 upregulation likely serves as a selection pressure for $p 53$ mutation.

While clinical observations only assist us in establishing potential correlation between $p 53$ inactivation and chronic inflammation, experimental approaches using $p 53^{\text {null }}$ mice allow us to draw a more solid conclusion about the crucial role of p53 inactivation in amplifying chronic inflammation. Studies by different laboratories reveal that $p 53^{\text {null }}$ mice are very susceptible to antigenand chemical-induced autoimmune diseases [49-51], whereas p53 gene transfer to inflamed tissues 
alleviates inflammation and autoimmune pathology [52]. Recent results from our laboratory and others further support the notion that $p 53$ inactivation/dysfunction skews tumor milieu towards pro-tumor inflammation, thereby promoting tumorigenesis and progression [25-27]. It is noteworthy that this $p 53$ inactivation-mediated gain of immunosuppressive function is not restricted to $p 53$ deletion because the mouse model of $p 53$ mutation, which mimics human hotspot $p 53$ mutations, also exemplifies exacerbated tissue inflammation in intestinal epithelial cells, liver, and breast tissues, leading to the development of colon, liver, and breast cancers, respectively [53-55]. Thus, these results suggest that while $p 53$ mutation/inactivation can be induced by environmental stress and tissue inflammation, the resulting inactivation of the p53 pathway in epithelial cells further amplifies chronic inflammation in the TME that likely promotes a vicious cycle of altered immunological milieu that promotes tumor progression and metastasis. Mechanistically, this p53 inactivation-induced inflammatory capacity of epithelial cells is likely a result of nuclear factor $\mathrm{k}$-light-chain-enhancer of activated B cells (NF- $\mathrm{kB}$ )-mediated production of inflammatory cytokines, which is discussed in the molecular mechanism section.

\subsubsection{Cancer-Associated Fibroblasts}

Besides the direct pro-inflammatory effects of $p 53$ mutation in epithelium, early studies indicate that tumor cells also impact the TME via altering the function and properties of adjacent cells, including CAFs. Fibroblasts have long been implicated in chronic inflammation and tumorigenesis by providing the signals for leukocyte recruitment, survival, and retention [56-58]. Although our understanding of CAFs on immune regulation is still evolving, recent results suggest that CAFs are somewhat reminiscent of the specialized fibroblastic reticular cells of the secondary lymphoid tissues that are known to be vital in recruiting, organizing leukocytes, and regulating immune responses [59-64].

Interestingly, $p 53$ mutations are detected in the CAFs of highly inflamed cancers that maintain an intact p53 pathway [65-67]. Moreover, these $p 53$ mutations in CAFs are associated with an increased rate of tumor metastasis and poor prognosis $[65,66,68]$. Mechanistically, it is demonstrated that the pro-tumor and pro-inflammatory effects of $p 53$-inactivated CAFs is mediated through enhanced production of cytokines and chemokines, including C-X-C motif chemokine ligand 12 (CXCL12)/stromal cell-derived factor 1 (SDF-1) and interleukin (IL)-6, which markedly affect both immune cell composition and function in the TME [25,32,57,58,69-71]. Furthermore, recent studies in our laboratory illustrate that fibroblastic stromal network in the TME of $p 53^{\text {null }}$ mice enhances MDSC proliferation and accumulation, thereby exacerbating immunosuppression and tumor progression [25]. It is also reported that $p 53$ dysfunction in CAFs serves as a selective pressure for the transformation of adjacent epithelial cells [33], which underscores the importance of functional p53 in other components of the TME in suppressing tumor initiation, progression, and metastases. More comprehensive studies are needed to further delineate the multiple pathways that CAFs are involved in for regulating the immune landscape of the TME.

\subsubsection{Immune Cells}

Immune cells constitute an important cellular compartment of the TME (Figure 1), although their abundancy varies greatly among different tumor types and from individual to individual. It is now increasingly appreciated that their abundancy, especially subset composition, is associated with disease progression and clinical prognosis [72-75]. Productive antitumor immunity heavily relies on the number and quality of activated effector T cells, whereas the existence and high frequency of immunosuppressive Treg and MDSCs are detrimental for immune-mediated tumor control.

Clinically, p53 mutations are less frequently detected in immune cells. Even in hematopoietic malignancies that are associated with $p 53$ mutations, the potential effects of p53 dysfunction/inactivation on host immune regulation have been largely overlooked. Thus, our understanding and assumption of immune cell p53 inactivation in altering host immune response and function is derived from experimental observations using $p 53^{\text {null }}$ mice. For instance, 
Zheng et al. showed that $p 53$ inactivation enhanced the production of inflammatory cytokines IL-1, -6 , and -12 by macrophages [50]. Furthermore, experimental results from our laboratory and others demonstrated that in addition to overall enhanced IL-6 production, $p 53$ inactivation in T cells also enhanced their differentiation to $\mathrm{T}$ helper Th17 cells [26,50,51]. Recent studies also demonstrated that $p 53$ inactivation compromises Treg differentiation, which shifts the balance between tolerance and inflammation towards inflammation [76,77]. Because Th17/IL-17 activity has been linked to inflammation, autoimmunity, and tumorigenesis [78-80], these results verify that $p 53$ inactivation in immune cells augments inflammation-induced tumorigenesis via multiple pathways, such as enhancing production of inflammatory cytokines and chemokines, promoting the differentiation and function of Th17 cells, and suppressing the differentiation of Treg. This crucial role of p53 in suppressing chronic inflammation is also confirmed by gene delivery experiments showing that $p 53$ gene transfer suppresses inflammation and autoimmunity [17,50].

It is noteworthy that, clinically, functional inactivation of the $\mathrm{p} 53$ pathway in immune cells or other cellular subsets may occur in the absence of $p 53$ mutation. It has been shown that overexpression of the natural p53 inhibitory protein mouse double minute 2 homolog (MDM2) or expression of certain viral proteins upon viral infection, such as human papillomavirus (HPV) E6 and human T-lymphotropic virus 1 (HLTV-1), also lead to inhibition of p53 activity, which has been linked to tumorigenesis [81-84]. Interestingly, HTLV-1 infection appears to be associated with increased development of autoimmune diseases, including RA, SS, and systemic lupus erythematosus (SLE) [85], although it is yet to be determined whether this HTLV-1-induced chronic inflammation is at least partially resulted by $p 53$ dysfunction in immune cells.

\subsection{Molecular Pathways that Link p53 Dysfunction and Inflammation}

\subsubsection{NF- $\kappa B$ Hyperactivity}

$\mathrm{NF}-\mathrm{kB}$, as a crucial transcription factor, is implicated in inflammation and tumorigenesis. Interestingly, it has been frequently reported in various experimental systems that NF- $\mathrm{kB}$ activity often shows a negative correlation with that of p53 $[17,86,87]$. Molecular studies defining the underlying mechanism of the reciprocal activities between p53 and NF- $\mathrm{kB}$ suggested that it is likely caused by their competition for the limited transcription coactivator $\mathrm{p} 300$ and the cAMP response element binding protein (CREB)-binding protein $[17,86,87]$. Moreover, recent studies demonstrate that p53 can also suppress the NF-KB pathway via directly inhibiting the promoter activity of NF- $\mathrm{kB}$ subunit p65 or indirectly repressing the activity of an IKB $\alpha$ kinase, IKK $\alpha$ [87-89]. In agreement with this notion, our study and those of others also demonstrated that $p 53$ inactivation causes hyperactivity of NF- $\mathrm{kB}$ pathway in $p 53^{\text {null }} \mathrm{T}$ cells, macrophages, and intestinal epithelium $[26,50,55,89]$. Therefore, highly activated NF- $\mathrm{kB}$ pathway in cancer cells, stroma, and immune cells all lead to elevated production of inflammatory cytokines and chemokines, thereby promoting chronic inflammation and tumorigenesis $[26,50,55,89]$.

Nevertheless, the reciprocal activation of $\mathrm{p} 53$ and NF- $\mathrm{kB}$ pathways is likely context dependent because under certain circumstances co-activation of p53 and NF- KB was also observed $[17,90]$. In a recent study involving human macrophages, it was demonstrated that $\mathrm{p} 53$ and NF- $\mathrm{kB}$ co-regulate IL-6 production [90]. Additionally, senescent cells with highly activated p53 pathway secrete numerous inflammatory cytokines, chemokines, growth factors, and other soluble proteins via activating the NF-kB pathway [91,92].

\subsubsection{Signal Transducer and Activators of Transcription Pathways}

Signal transducer and activators of transcription (STAT) is a group of crucial transcription factors that instigate signals of cytokines, chemokines, and growth factors to biological function. Various STAT molecules respond to different environmental cues during various biological events. Among them, STAT3 hyperactivity has been shown to be crucial in the development of myeloid-suppressor cells 
and inflammation-induced tumorigenesis [36,93-96]. Interestingly, early studies suggested that p53 activity suppresses that of STAT3 so that $p 53$ inactivation leads to STAT3 activation [97]. Our results of $p 53$ inactivation-associated autoimmune mouse model revealed that hyperactivated STAT3 and NF- $\mathrm{kB}$ pathways in mouse $\mathrm{T}$ cells are drivers of Th17 differentiation and autoimmune pathology [26]. Furthermore, the study by Zheng et al. using $p 53^{\text {null }}$ in an autoimmune disease model revealed that $p 53$ inactivation in macrophages resulted in a hyper-responsive STAT1 pathway, leading to enhanced production of inflammatory cytokines [50]. Besides the supportive roles of STAT3 in Th17 differentiation in $p 53^{\text {null }}$ mice, it is also reported that $\mathrm{p} 53$ activation-induced suppression of Th17 differentiation is mediated through activation of STAT5 [76]. Therefore, p53 activity regulates host immune response partially through modulating the balanced activity of various STAT pathways.

\subsubsection{Other Immune Regulatory Molecules and Pathways}

Similar to previous reports of $p 53$ inactivation-promoted production of inflammatory molecules, such as IL-6, cyclooxygenase 2 (Cox-2), and inducible nitric oxide synthase (iNOS) via NF- $\mathrm{kB}$ and STAT pathways $[16,17,86], p 53$ inactivation also enhances the production of macrophage migration inhibitory factor (MIF), a pro-inflammatory cytokine that promotes inflammation via the NF- $\mathrm{KB}$ pathway [98-101]. Recently, the effects of $p 53$ dysfunction/mutation-induced inflammatory and/or immunosuppressive function have been broadened to the upregulation of programmed death-ligand 1 (PD-L1) via microRNA miR34 [102]. Furthermore, p53 missense mutant binds and inhibits another tumor suppressor disabled homolog 2-interacting protein (DAB2IP) to promote inflammation through activation of NF- $\mathrm{kB}[44,52]$.

Collectively, these experimental and clinical data exemplify that $p 53$ dysfunction in tumors or other cellular populations of the TME also promotes tumor progression and metastasis via enhancing chronic inflammation. This process involves considerable modulations of molecular and cellular composition, as well as tissue structure, reminiscent of tissue remolding and wound healing, which controls the immunosuppressive nature of the TME $[13,35,38-41,103]$.

\section{Targeting the p53 Pathway in the Tumor Microenvironment for Improving Systemic Antitumor Immunity}

As discussed earlier, acute burst of immune activation, different from chronic inflammation, supports productive and protective immunity. Effective immune-mediated tumor eradication requires tumor antigen-specific, systemic, and durable T cell-mediated adaptive immunity [104-107]. Because p53 inactivation leads to pro-tumor chronic inflammation and immunosuppression in the TME, we hypothesize that p53 activation or restoration in the TME reverses immunosuppression and reshapes the immunological landscape to support productive antitumor immunity for better tumor control. In fact, genetic manipulations using mouse models demonstrated that p53 reactivation in p53-deficient tumors induced tumor apoptosis and/or senescence, which resulted in recruitment and activation of innate immune cells, including NK cells and macrophages, for the clearance of the apoptotic or senescent tumor cells [30,31]. However, it is largely unknown whether p53 activation in the TME also promotes tumor-specific T cell activation. Based on the existing reports of potential cellular and molecular mechanisms of p53 activation in enhancing innate immunity, our knowledge of the cooperativity between innate and adaptive immunity, and some of our unpublished observations, we discuss here the contribution of various cellular and molecular pathways to p53 activation-mediated immune activation and potential development of targeting the p53 pathway as a novel immunotherapy strategy for cancer control and clearance.

\subsection{Effects of p53 Activation on Innate Immunity}

As the first line of host defense to pathogenic and environmental insults, innate immune cells are activated almost instantaneously upon encountering pathogenic threats to kill and engulf the invaders in a non-antigen-specific manner. In general, the activation is initiated by the stimulation of 
Toll-like receptors (TLRs) on the innate immune cell surface through pathogen-associated molecular pattern (PAMP) or internal stress-related damage-associated molecular pattern (DAMP) signals, such as single-stranded DNA, double-stranded RNA, and bacterial-like DNA fragments containing CpG motifs. This PAMP or DAMP pathway-mediated activation of innate cells results in their enhanced type I interferon (IFN) production, which further activates the myeloid cells for their activation of adaptive immunity. Recent studies also showed that radiotherapy-induced DNA damage resulted in elevated production of type I IFN, which stimulated tumor antigen process and presentation by DCs and subsequent activation of adaptive antitumor immunity [108].

Interestingly, recent compelling evidence suggests that therapeutic efficacy of radio- and chemotherapy, both involving DNA damage and activation of the p53 pathway, is largely dependent on their capacity of eliciting antitumor immunity [109-112]. Mechanistically, this process is first initiated by therapy-induced tumor immunogenic cell death (ICD), usually characterized by three hallmark markers: exposure of an endoplasmic reticulum (ER) protein, calreticulin (CALR), at the cell surface, release of the chromatin protein high-mobility group box 1 (HMGB1), and ATP to the extracellular space $[109,111]$. Extracellular exposure of these molecules leads to activation of innate immune cells via various pathways, such as TLR-4 and purinergic receptors [92,113]. Moreover, it has also been reported that p53 activation directly enhances the expression and function of TLR-3 and/or -8 in human cancers, epithelial cell lines, lymphocytes, and type I alveolar cells $[27,114,115]$. Furthermore, a recent study revealed that p53 by direct binding to the promoter region of IL-12 enhances DC function and capacity of promoting adaptive antitumor immunity [116].

Besides myeloid cells, NK cells potentially can be activated by DNA damage-induced upregulation of UL16 binding protein 2 (ULBP2), a natural killer group 2D (NKG2D) ligand, which greatly enhance NK-mediated tumor elimination [117-121].

Together, these results suggest that p53 activation likely promotes the activation of innate immunity via multiple molecular pathways. Based on existing literature and our unpublished observations, we propose that some of the immunostimulatory effects of conventional radio- and chemotherapy are mediated through p53-associated TLR and IFN pathways. It is yet to be verified clinically whether therapy-induced p53 activation contributes to the induction of antitumor immunity.

\subsection{Effects of p53 Activation on Adaptive Immunity}

Recent advances in tumor immunology and immunological assessment of the therapeutic effects of conventional radio- and chemotherapy suggest that the activation of the adaptive antitumor immunity is indispensable for their therapeutic benefits [109-111]. Because innate immunity serves as a crucial activator of the adaptive immune responses, p53 activation-mediated stimulation of innate immunity, especially DC activation, will also promote adaptive immunity.

On the other hand, our understanding of the direct effects of p53 activation on $\mathrm{T}$ and B activation is still very limited. Early studies showed that p53 activation is readily detected in mitogen-stimulated or T cell receptor (TCR) ligation-activated murine and human T cells [122,123]. However, for total $\mathrm{T}$ cell population, this elevated p53 activity does not appear to impose detrimental effects on their survival or function $[45-47,124]$. Only until recently, it was believed that p53 activation during T cell activation serves as a selection factor for eliminating non-productive T cells that are stimulated by IL-2, but not fully activated by antigen-specific TCR ligation [125]. It is clear that more in-depth studies are required to advance our comprehension and appreciation of the regulatory role of p53 in adaptive immunity.

Altogether, p53 activation can directly enhance $\mathrm{T}$ cell antitumor immunity by selecting effectively activated effector $\mathrm{T}$ cells and indirectly by stimulating innate immune responses that enhance the tumor antigen update, presentation, and activation of myeloid cells for promoting activation of tumor antigen-specific adaptive immunity. 


\subsection{Potential Application of Targeting the p53 Pathway for Harnessing Host Antitumor Immunity}

Because $p 53$ mutation/inactivation is one of major causes of cancer, targeting the p53 pathway for direct tumoricidal effects has been an important strategy for cancer treatment [126-128]. Immunologically, activation of the p53 pathway in the TME elicits both innate and adaptive immunity and, thus, can be exploited to harness antitumor immunity for additional therapeutic gains. Here, we will focus our discussion on approaches that directly activate the p53 pathway via pharmacological activators.

It is noteworthy that current approaches of targeting the p53 pathway mostly focus on activating or restoring p53 function in tumor cells. As discussed above, p53 activation also greatly impacts the function and survival of immune cells within the TME. Because most immune cells are more sensitive to p53 activation-induced cell death than tumor cells as shown in a previous report [129] and our unpublished observation, targeted p53 activation as an immunotherapy approach will require different dosing and delivery strategies. Specifically, p53 activation-elicited antitumor immunity does not rely on a global or uniform activation of the p53 pathway throughout the entire TME. In fact, local p53 activation that sufficiently induces tumor death and activation of dendritic cells and macrophages in the confined area of the TME can be effective in amplifying T cell-mediated tumor antigen-specific antitumor immunity (Figure 2). These in situ activated tumor antigen-specific T cells will circulate systemically to provide protection and to reach and eliminate distal metastatic tumors (Figure 2). Overall, $p 53$ reactivation or restoration reverses the immunosuppressive landscape of the TME and promotes antitumor immunity for better tumor control.

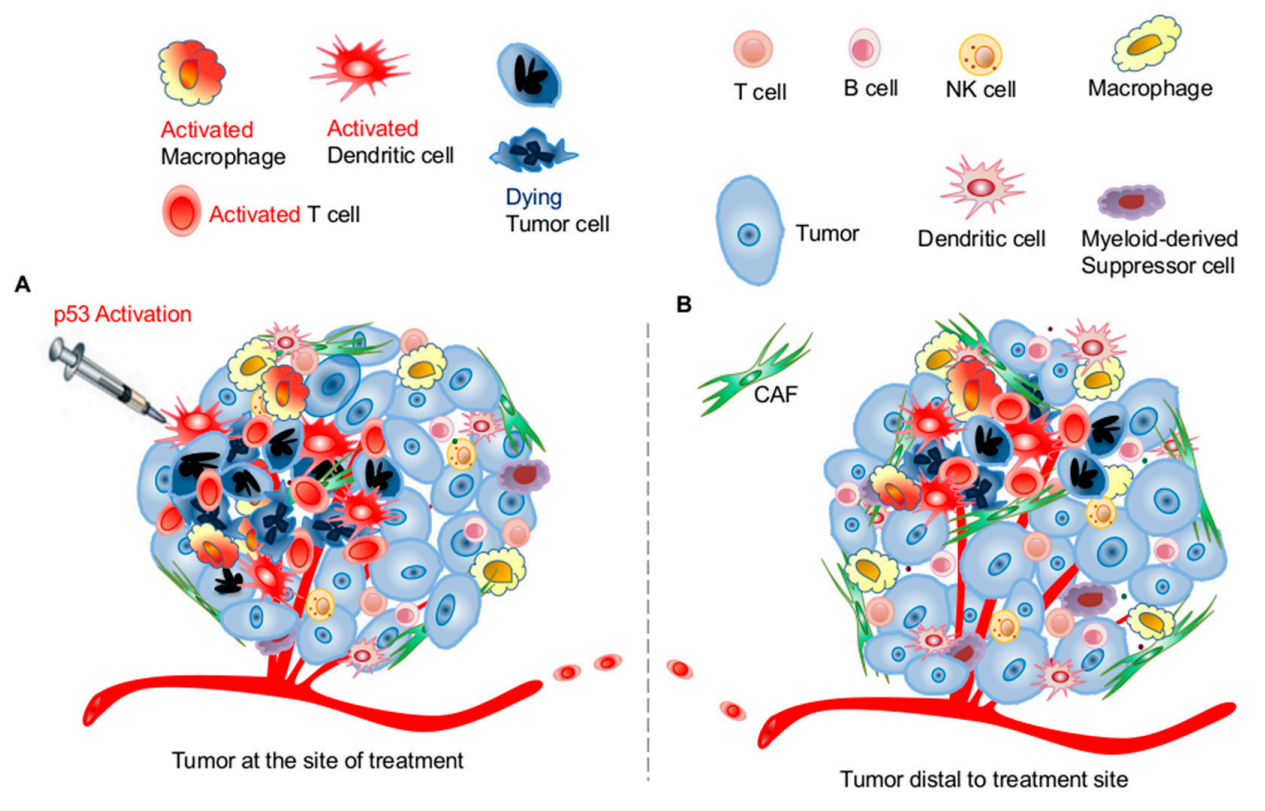

Figure 2. Targeting the p53 pathway in the tumor microenvironment (TME) to activate antitumor immunity for systemic tumor control. Local activation of the p53 pathway in the TME can be achieved via intratumoral injection of specific p53 activators (A). This induces tumor immunogenic cell death and subsequent activation of macrophages and dendritic cells at confined areas around the site of injection. Activated macrophages and DCs update and present tumor antigens to activate T cells that kill more tumor cells (A). This T cell-mediated tumor killing further amplifies the activation events of macrophages, DCs, and T cells that execute and expand tumor killing around the injection site (B). Importantly, activated T cells travel in circulation through blood and lymphatic vasculatures to find and kill additional tumors distal to the site of injection (B). Activated systemic adaptive immunity via local p53 activation in the TME supports systemic tumor control and regression. CAF: cancer-associated fibroblasts. 


\subsubsection{Small Molecule-Based Therapy Targeting the p53-MDM2 Axis}

The E3 ubiquitin ligase MDM2 is a natural, crucial p53 inhibitor. Thus, a pharmacological inhibitor of MDM2, such as nutlin-3a, activates wild-type p53 [130,131]. Similarly, reactivation of p53 and induction of tumor cell apoptosis (RITA) also induces p53 activation by binding HDM2 human double minus-2, the human analog of MDM2 (HDM2), [132,133]. Thus far, most of the published studies focus on MDM2-mediated tumor cell apoptosis. Interestingly, recent reports demonstrate that nutlin-3 also regulates host immune response by activating antigen-presenting cells, including dendritic cells $[134,135]$, thus suggesting that activating the p53 pathway can also be explored for its immunomodulatory effects to improve therapeutic outcome. In fact, recent unpublished results from our laboratory demonstrated that intratumoral local delivery of nutlin-3a induced ICD of tumors that activate dendritic cells and macrophages, which subsequently activate tumor-specific cluster of differenctiation (CD) $8 \mathrm{~T}$ cells. These activated tumor-specific $\mathrm{T}$ cells not only eliminated tumor cells at the site of nutlin delivery, but also resulted in regression of tumors distal to the nutlin-injection site (Figure 2).

\subsubsection{Restoration of Mutant p53 to Wild-Type Configuration and Function}

Because many p53 mutants are associated with conformational changes that hinder their DNA binding and transactivation capacity, small molecules other than MDM2 inhibitors are needed to restore the function of $p 53$ mutants. p53 reactivation and induction of massive apoptosis-1 (PRIMA) and mutant p53 reactivation and induction of rapid apoptosis (MIRA-3) are representative molecules that convert mutant p53 to restore wild-type function [136,137]. Even though the immunoregulatory property of these pharmacological activators has yet to be explored, given their well understood mechanism of action, it is believed they will broaden the application of targeting the p53 pathway for immunological gains in tumors incurring $p 53$ mutations. Considering the observed non-overlapping p53 mutations in either tumors or stromal compartment of the TME, such as tumor or CAFs, we propose that combination of p53 reactivators with MDM2 inhibitors will broaden the spectrum of p53 activation in the TME regardless of the $p 53$ status, thereby likely representing a more effective approach for promoting antitumor immunity and overcoming tumor-induced immune tolerance.

\subsubsection{Combining p53-Activation Therapy with Other Active Immunotherapy to Improve Therapeutic Efficacy}

Clinically and experimentally, compelling evidence demonstrates that effective cancer therapy requires multipronged combinational approaches that not only debunk tumors, but also elicit strong antitumor immunity, which is otherwise unachievable by monotherapy of surgery, radiation, chemotherapy, or even single-pronged immunotherapy [109,138-140]. One of the crucial factors that dictates immunotherapy outcome is efficient recruitment of immune effectors, especially activated tumor-specific CD8 T cells, to the TME. Given the diversity of immune cell infiltration in different tumors and individuals, it is important to employ other potent immunotherapy approaches for enhancing recruitment of immune cells and for maintaining CD8 effector T cell function at the time of p53 activation-based immunotherapy.

Pharmacological activation of the p53 pathway in the TME represents a new and exciting immunological strategy to reverse immunosuppression of the TME and to promote systemic, lasting antitumor immunity for improved tumor control. Certainly, more in-depth mechanistic and preclinical studies are warranted before their broader clinical applications can be fully appreciated and developed.

\section{Conclusions}

During the past 30 years, our understanding and appreciation of the complexity of the p53 pathway and its regulation in myriad biological processes have been greatly enriched. Nevertheless, our comprehension of p53 in all aspects of physiological processes is far from complete. From an 
immunological aspect, our knowledge of its participation in host immune surveillance and tumor immune evasion is limited. Compelling evidence supports a crucial immunological consequence of p53 dysfunction in tumorigenesis and tumor progression. It is, therefore, imperative that targeting the 553 pathway is incorporated into an active immunotherapy approach for maximal therapeutic benefits, which certainly relies on our better comprehension of the specific mechanisms/pathways through which p53 actively regulates host immune responses and the immunological landscape of the tumor microenvironment.

Acknowledgments: This study is supported by 01CA169133 from NCI/NIH and funds from GRU Cancer Center to Yan Cui.

Author Contributions: Yan Cui and Gang Guo reviewed the literature and wrote the manuscript.

Conflicts of Interest: The authors declare no conflict of interest.

\section{References}

1. Vousden, K.H.; Lane, D.P. p53 in health and disease. Nat. Rev. 2007, 8, 275-283. [CrossRef] [PubMed]

2. Levine, A.J. p53, the cellular gatekeeper for growth and division. Cell 1997, 88, 323-331. [CrossRef]

3. Levine, A.J.; Oren, M. The first 30 years of p53: Growing ever more complex. Nat. Rev. Cancer 2009, 9, 749-758. [CrossRef] [PubMed]

4. Olivier, M.; Hollstein, M.; Hainaut, P. TP53 mutations in human cancers: Origins, consequences, and clinical use. Cold Spring Harb. Perspect. Biol. 2010, 2, a001008. [CrossRef] [PubMed]

5. Bensaad, K.; Tsuruta, A.; Selak, M.A.; Vidal, M.N.; Nakano, K.; Bartrons, R.; Gottlieb, E.; Vousden, K.H. TIGAR, a p53-inducible regulator of glycolysis and apoptosis. Cell 2006, 126, 107-120. [CrossRef] [PubMed]

6. Lane, D.; Levine, A. p53 Research: The past thirty years and the next thirty years. Cold Spring Harb. Perspect. Biol. 2010, 2, a000893. [CrossRef] [PubMed]

7. Vousden, K.H.; Prives, C. Blinded by the light: The growing complexity of p53. Cell 2009, 137, 413-431. [CrossRef] [PubMed]

8. Menendez, D.; Inga, A.; Resnick, M.A. The expanding universe of p53 targets. Nat. Rev. Cancer 2009, 9, 724-737. [CrossRef] [PubMed]

9. Aylon, Y.; Oren, M. New plays in the p53 theater. Curr. Opin. Genet. Dev. 2011, 21, 86-92. [CrossRef] [PubMed]

10. Yi, L.; Lu, C.; Hu, W.; Sun, Y.; Levine, A.J. Multiple roles of p53-related pathways in somatic cell reprogramming and stem cell differentiation. Cancer Res. 2012, 72, 5635-5645. [CrossRef] [PubMed]

11. Muller, P.A.; Caswell, P.T.; Doyle, B.; Iwanicki, M.P.; Tan, E.H.; Karim, S.; Lukashchuk, N.; Gillespie, D.A.; Ludwig, R.L.; Gosselin, P.; et al. Mutant p53 drives invasion by promoting integrin recycling. Cell 2009, 139, 1327-1341. [CrossRef] [PubMed]

12. Rivlin, N.; Koifman, G.; Rotter, V. p53 orchestrates between normal differentiation and cancer. Semin. Cancer Biol. 2015, 32, 10-17. [CrossRef] [PubMed]

13. Hanahan, D.; Weinberg, R.A. Hallmarks of cancer: The next generation. Cell 2011, 144, 646-674. [CrossRef] [PubMed]

14. Hussain, S.P.; Hollstein, M.H.; Harris, C.C. p53 tumor suppressor gene: At the crossroads of molecular carcinogenesis, molecular epidemiology, and human risk assessment. Ann. N. Y. Acad. Sci. 2000, 919, 79-85. [CrossRef] [PubMed]

15. Hussain, S.P.; Amstad, P.; Raja, K.; Ambs, S.; Nagashima, M.; Bennett, W.P.; Shields, P.G.; Ham, A.J.; Swenberg, J.A.; Marrogi, A.J.; et al. Increased p53 mutation load in noncancerous colon tissue from ulcerative colitis: A cancer-prone chronic inflammatory disease. Cancer Res. 2000, 60, 3333-3337. [PubMed]

16. Schetter, A.J.; Heegaard, N.H.; Harris, C.C. Inflammation and cancer: Interweaving microRNA, free radical, cytokine and p53 pathways. Carcinogenesis 2010, 31, 37-49. [CrossRef] [PubMed]

17. Gudkov, A.V.; Gurova, K.V.; Komarova, E.A. Inflammation and p53: A tale of two stresses. Genes Cancer 2011, 2, 503-516. [CrossRef] [PubMed]

18. Colotta, F.; Allavena, P.; Sica, A.; Garlanda, C.; Mantovani, A. Cancer-related inflammation, the seventh hallmark of cancer: Links to genetic instability. Carcinogenesis 2009, 30, 1073-1081. [CrossRef] [PubMed] 
19. Grivennikov, S.I.; Greten, F.R.; Karin, M. Immunity, inflammation, and cancer. Cell 2010, 140, $883-899$. [CrossRef] [PubMed]

20. DeLeo, A.B.; Whiteside, T.L. Development of multi-epitope vaccines targeting wild-type sequence p53 peptides. Expert Rev. Vaccines 2008, 7, 1031-1040. [CrossRef] [PubMed]

21. Vermeij, R.; Leffers, N.; van der Burg, S.H.; Melief, C.J.; Daemen, T.; Nijman, H.W. Immunological and clinical effects of vaccines targeting p53-overexpressing malignancies. J. Biomed. Biotechnol. 2011, 2011, 702146. [CrossRef] [PubMed]

22. Chiappori, A.A.; Soliman, H.; Janssen, W.E.; Antonia, S.J.; Gabrilovich, D.I. INGN-225: A dendritic cell-based p53 vaccine (Ad.p53-DC) in small cell lung cancer: Observed association between immune response and enhanced chemotherapy effect. Expert Opin. Biol. Ther. 2010, 10, 983-991. [CrossRef] [PubMed]

23. Soussi, T. p53 alterations in human cancer: More questions than answers. Oncogene 2007, 26, $2145-2156$. [CrossRef] [PubMed]

24. Soussi, T.; Hamroun, D.; Hjortsberg, L.; Rubio-Nevado, J.M.; Fournier, J.L.; Beroud, C. MUT-TP53 2.0: A novel versatile matrix for statistical analysis of TP53 mutations in human cancer. Hum. Mutat. 2010, 31, 1020-1025. [CrossRef] [PubMed]

25. Guo, G.; Marrero, L.; Rodriguez, P.; Del Valle, L.; Ochoa, A.; Cui, Y. Trp53 inactivation in the tumor microenvironment promotes tumor progression by expanding the immunosuppressive lymphoid-like stromal network. Cancer Res. 2013, 73, 1668-1675. [CrossRef] [PubMed]

26. Zhang, S.; Zheng, M.; Kibe, R.; Huang, Y.; Marrero, L.; Warren, S.; Zieske, A.W.; Iwakuma, T.; Kolls, J.K.; Cui, Y. Trp53 negatively regulates autoimmunity via the STAT3-Th17 axis. FASEB J. 2011, 25, 2387-2398. [CrossRef] [PubMed]

27. Menendez, D.; Shatz, M.; Resnick, M.A. Interactions between the tumor suppressor p53 and immune responses. Curr. Opin. Oncol. 2013, 25, 85-92. [CrossRef] [PubMed]

28. Komarova, E.A.; Krivokrysenko, V.; Wang, K.; Neznanov, N.; Chernov, M.V.; Komarov, P.G.; Brennan, M.L.; Golovkina, T.V.; Rokhlin, O.W.; Kuprash, D.V.; et al. p53 is a suppressor of inflammatory response in mice. FASEB J. 2005, 19, 1030-1032. [CrossRef] [PubMed]

29. Martins, C.P.; Brown-Swigart, L.; Evan, G.I. Modeling the therapeutic efficacy of p53 restoration in tumors. Cell 2006, 127, 1323-1334. [CrossRef] [PubMed]

30. Ventura, A.; Kirsch, D.G.; McLaughlin, M.E.; Tuveson, D.A.; Grimm, J.; Lintault, L.; Newman, J.; Reczek, E.E.; Weissleder, R.; Jacks, T. Restoration of p53 function leads to tumour regression in vivo. Nature 2007, 445, 661-665. [CrossRef] [PubMed]

31. Xue, W.; Zender, L.; Miething, C.; Dickins, R.A.; Hernando, E.; Krizhanovsky, V.; Cordon-Cardo, C.; Lowe, S.W. Senescence and tumour clearance is triggered by p53 restoration in murine liver carcinomas. Nature 2007, 445, 656-660. [CrossRef] [PubMed]

32. Kiaris, H.; Chatzistamou, I.; Trimis, G.; Frangou-Plemmenou, M.; Pafiti-Kondi, A.; Kalofoutis, A. Evidence for nonautonomous effect of p53 tumor suppressor in carcinogenesis. Cancer Res. 2005, 65, 1627-1630. [CrossRef] [PubMed]

33. Lujambio, A.; Akkari, L.; Simon, J.; Grace, D.; Tschaharganeh, D.F.; Bolden, J.E.; Zhao, Z.; Thapar, V.; Joyce, J.A.; Krizhanovsky, V.; et al. Non-cell-autonomous tumor suppression by p53. Cell 2013, 153, 449-460. [CrossRef] [PubMed]

34. Coussens, L.M.; Werb, Z. Inflammation and cancer. Nature 2002, 420, 860-867. [CrossRef] [PubMed]

35. Ostrand-Rosenberg, S.; Sinha, P. Myeloid-derived suppressor cells: Linking inflammation and cancer. J. Immunol. 2009, 182, 4499-4506. [CrossRef] [PubMed]

36. Ben-Neriah, Y.; Karin, M. Inflammation meets cancer, with NF-kB as the matchmaker. Nat. Immunol. 2011, 12, 715-723. [CrossRef] [PubMed]

37. Gajewski, T.F.; Meng, Y.; Blank, C.; Brown, I.; Kacha, A.; Kline, J.; Harlin, H. Immune resistance orchestrated by the tumor microenvironment. Immunol. Rev. 2006, 213, 131-145. [CrossRef] [PubMed]

38. Kerkar, S.P.; Restifo, N.P. Cellular constituents of immune escape within the tumor microenvironment. Cancer Res. 2012, 72, 3125-3130. [CrossRef] [PubMed]

39. Swartz, M.A.; Iida, N.; Roberts, E.W.; Sangaletti, S.; Wong, M.H.; Yull, F.E.; Coussens, L.M.; DeClerck, Y.A. Tumor microenvironment complexity: Emerging roles in cancer therapy. Cancer Res. 2012, 72, 2473-2480. [CrossRef] [PubMed] 
40. Gabrilovich, D.I.; Nagaraj, S. Myeloid-derived suppressor cells as regulators of the immune system. Nat. Rev. Immunol. 2009, 9, 162-174. [CrossRef] [PubMed]

41. Gabrilovich, D.I.; Ostrand-Rosenberg, S.; Bronte, V. Coordinated regulation of myeloid cells by tumours. Nat. Rev. Immunol. 2012, 12, 253-268. [CrossRef] [PubMed]

42. Trinchieri, G. Cancer and inflammation: An old intuition with rapidly evolving new concepts. Annu. Rev. Immunol. 2012, 30, 677-706. [CrossRef] [PubMed]

43. Karin, M.; Lawrence, T.; Nizet, V. Innate immunity gone awry: Linking microbial infections to chronic inflammation and cancer. Cell 2006, 124, 823-835. [CrossRef]

44. Cooks, T.; Harris, C.C.; Oren, M. Caught in the cross fire: p53 in inflammation. Carcinogenesis 2014, 35, 1680-1690. [CrossRef] [PubMed]

45. Tak, P.P.; Zvaifler, N.J.; Green, D.R.; Firestein, G.S. Rheumatoid arthritis and p53: How oxidative stress might alter the course of inflammatory diseases. Immunol. Today 2000, 21, 78-82. [CrossRef]

46. Yamanishi, Y.; Boyle, D.L.; Rosengren, S.; Green, D.R.; Zvaifler, N.J.; Firestein, G.S. Regional analysis of p53 mutations in rheumatoid arthritis synovium. Proc. Natl. Acad. Sci. USA 2002, 99, 10025-10030. [CrossRef] [PubMed]

47. Tapinos, N.I.; Polihronis, M.; Moutsopoulos, H.M. Lymphoma development in Sjogren's syndrome: Novel p53 mutations. Arthritis Rheum. 1999, 42, 1466-1472. [CrossRef]

48. Staib, F.; Robles, A.I.; Varticovski, L.; Wang, X.W.; Zeeberg, B.R.; Sirotin, M.; Zhurkin, V.B.; Hofseth, L.J.; Hussain, S.P.; Weinstein, J.N.; et al. The p53 tumor suppressor network is a key responder to microenvironmental components of chronic inflammatory stress. Cancer Res. 2005, 65, 10255-10264. [CrossRef] [PubMed]

49. Yamanishi, Y.; Boyle, D.L.; Pinkoski, M.J.; Mahboubi, A.; Lin, T.; Han, Z.; Zvaifler, N.J.; Green, D.R.; Firestein, G.S. Regulation of joint destruction and inflammation by p53 in collagen-induced arthritis. Am. J. Pathol. 2002, 160, 123-130. [CrossRef]

50. Zheng, S.J.; Lamhamedi-Cherradi, S.E.; Wang, P.; Xu, L.; Chen, Y.H. Tumor suppressor p53 inhibits autoimmune inflammation and macrophage function. Diabetes 2005, 54, 1423-1428. [CrossRef] [PubMed]

51. Okuda, Y.; Okuda, M.; Bernard, C.C. Regulatory role of p53 in experimental autoimmune encephalomyelitis. J. Neuroimmunol. 2003, 135, 29-37. [CrossRef]

52. Yao, Q.; Wang, S.; Glorioso, J.C.; Evans, C.H.; Robbins, P.D.; Ghivizzani, S.C.; Oligino, T.J. Gene transfer of p53 to arthritic joints stimulates synovial apoptosis and inhibits inflammation. Mol. Ther 2001, 3, 901-910. [CrossRef] [PubMed]

53. Di Minin, G.; Bellazzo, A.; Dal Ferro, M.; Chiaruttini, G.; Nuzzo, S.; Bicciato, S.; Piazza, S.; Rami, D.; Bulla, R.; Sommaggio, R.; et al. Mutant p53 reprograms TNF signaling in cancer cells through interaction with the tumor suppressor DAB2IP. Mol. Cell 2014, 56, 617-629. [CrossRef] [PubMed]

54. Dibra, D.; Xia, X.; Mitra, A.; Cutrera, J.J.; Lozano, G.; Li, S. Mutant p53 in concert with an interleukin-27 receptor alpha deficiency causes spontaneous liver inflammation, fibrosis, and steatosis in mice. Hepatology 2016, 63, 1000-1012. [CrossRef] [PubMed]

55. Schwitalla, S.; Ziegler, P.K.; Horst, D.; Becker, V.; Kerle, I.; Begus-Nahrmann, Y.; Lechel, A.; Rudolph, K.L.; Langer, R.; Slotta-Huspenina, J.; et al. Loss of p53 in enterocytes generates an inflammatory microenvironment enabling invasion and lymph node metastasis of carcinogen-induced colorectal tumors. Cancer Cell 2013, 23, 93-106. [CrossRef] [PubMed]

56. Bhowmick, N.A.; Neilson, E.G.; Moses, H.L. Stromal fibroblasts in cancer initiation and progression. Nature 2004, 432, 332-337. [CrossRef] [PubMed]

57. Orimo, A.; Gupta, P.B.; Sgroi, D.C.; Arenzana-Seisdedos, F.; Delaunay, T.; Naeem, R.; Carey, V.J.; Richardson, A.L.; Weinberg, R.A. Stromal fibroblasts present in invasive human breast carcinomas promote tumor growth and angiogenesis through elevated SDF-1/CXCL12 secretion. Cell 2005, 121, 335-348. [CrossRef] [PubMed]

58. Orimo, A.; Weinberg, R.A. Stromal fibroblasts in cancer: A novel tumor-promoting cell type. Cell Cycle 2006, 5, 1597-1601. [CrossRef] [PubMed]

59. Shields, J.D.; Kourtis, I.C.; Tomei, A.A.; Roberts, J.M.; Swartz, M.A. Induction of lymphoidlike stroma and immune escape by tumors that express the chemokine CCL21. Science 2010, 328, 749-752. [CrossRef] [PubMed] 
60. Katakai, T.; Hara, T.; Sugai, M.; Gonda, H.; Shimizu, A. Lymph node fibroblastic reticular cells construct the stromal reticulum via contact with lymphocytes. J. Exp. Med. 2004, 200, 783-795. [CrossRef] [PubMed]

61. Fletcher, A.L.; Malhotra, D.; Turley, S.J. Lymph node stroma broaden the peripheral tolerance paradigm. Trends Immunol. 2011, 32, 12-18. [CrossRef] [PubMed]

62. Lee, J.W.; Epardaud, M.; Sun, J.; Becker, J.E.; Cheng, A.C.; Yonekura, A.R.; Heath, J.K.; Turley, S.J. Peripheral antigen display by lymph node stroma promotes T cell tolerance to intestinal self. Nat. Immunol. 2007, 8, 181-190. [CrossRef] [PubMed]

63. Turley, S.J.; Fletcher, A.L.; Elpek, K.G. The stromal and haematopoietic antigen-presenting cells that reside in secondary lymphoid organs. Nat. Rev. Immunol. 2010, 10, 813-825. [CrossRef] [PubMed]

64. Peduto, L.; Dulauroy, S.; Lochner, M.; Spath, G.F.; Morales, M.A.; Cumano, A.; Eberl, G. Inflammation recapitulates the ontogeny of lymphoid stromal cells. J. Immunol. 2009, 182, 5789-5799. [CrossRef] [PubMed]

65. Hill, R.; Song, Y.; Cardiff, R.D.; van Dyke, T. Selective evolution of stromal mesenchyme with p53 loss in response to epithelial tumorigenesis. Cell 2005, 123, 1001-1011. [CrossRef] [PubMed]

66. Patocs, A.; Zhang, L.; Xu, Y.; Weber, F.; Caldes, T.; Mutter, G.L.; Platzer, P.; Eng, C. Breast-cancer stromal cells with TP53 mutations and nodal metastases. N. Engl. J. Med. 2007, 357, 2543-2551. [CrossRef] [PubMed]

67. Yamanishi, Y.; Boyle, D.L.; Green, D.R.; Keystone, E.C.; Connor, A.; Zollman, S.; Firestein, G.S. p53 tumor suppressor gene mutations in fibroblast-like synoviocytes from erosion synovium and non-erosion synovium in rheumatoid arthritis. Arthritis Res. Ther. 2005, 7, R12-R18. [CrossRef] [PubMed]

68. Fukino, K.; Shen, L.; Patocs, A.; Mutter, G.L.; Eng, C. Genomic instability within tumor stroma and clinicopathological characteristics of sporadic primary invasive breast carcinoma. JAMA 2007, 297, 2103-2111. [CrossRef] [PubMed]

69. Orimo, A.; Weinberg, R.A. Heterogeneity of stromal fibroblasts in tumors. Cancer Biol. Ther. 2007, 6, 618-619. [CrossRef] [PubMed]

70. Addadi, Y.; Moskovits, N.; Granot, D.; Lozano, G.; Carmi, Y.; Apte, R.N.; Neeman, M.; Oren, M. p53 status in stromal fibroblasts modulates tumor growth in an SDF1-dependent manner. Cancer Res. 2010, 70, 9650-9658. [CrossRef] [PubMed]

71. Moskovits, N.; Kalinkovich, A.; Bar, J.; Lapidot, T.; Oren, M. p53 Attenuates cancer cell migration and invasion through repression of SDF-1/CXCL12 expression in stromal fibroblasts. Cancer Res. 2006, 66, 10671-10676. [CrossRef] [PubMed]

72. Mlecnik, B.; Bindea, G.; Kirilovsky, A.; Angell, H.K.; Obenauf, A.C.; Tosolini, M.; Church, S.E.; Maby, P.; Vasaturo, A.; Angelova, M.; et al. The tumor microenvironment and Immunoscore are critical determinants of dissemination to distant metastasis. Sci. Transl. Med. 2016, 8, 327ra26. [CrossRef] [PubMed]

73. Angell, H.; Galon, J. From the immune contexture to the Immunoscore: The role of prognostic and predictive immune markers in cancer. Curr. Opin. Immunol. 2013, 25, 261-267. [CrossRef] [PubMed]

74. Mlecnik, B.; Bindea, G.; Angell, H.K.; Maby, P.; Angelova, M.; Tougeron, D.; Church, S.E.; Lafontaine, L.; Fischer, M.; Fredriksen, T.; et al. Integrative analyses of colorectal cancer show Immunoscore is a stronger predictor of patient survival than microsatellite instability. Immunity 2016, 44, 698-711. [CrossRef] [PubMed]

75. Sun, C.; Xu, J.; Song, J.; Liu, C.; Wang, J.; Weng, C.; Sun, H.; Wei, H.; Xiao, W.; Sun, R.; et al. The predictive value of centre tumour $\mathrm{CD}^{+} \mathrm{T}$ cells in patients with hepatocellular carcinoma: Comparison with Immunoscore. Oncotarget 2015, 6, 35602-35615. [PubMed]

76. Park, J.S.; Lim, M.A.; Cho, M.L.; Ryu, J.G.; Moon, Y.M.; Jhun, J.Y.; Byun, J.K.; Kim, E.K.; Hwang, S.Y.; Ju, J.H.; et al. p53 controls autoimmune arthritis via STAT-mediated regulation of the Th17 cell/Treg cell balance in mice. Arthritis Rheuma. 2013, 65, 949-959. [CrossRef] [PubMed]

77. Kawashima, H.; Takatori, H.; Suzuki, K.; Iwata, A.; Yokota, M.; Suto, A.; Minamino, T.; Hirose, K.; Nakajima, H. Tumor suppressor p53 inhibits systemic autoimmune diseases by inducing regulatory $\mathrm{T}$ cells. J. Immunol. 2013, 191, 3614-3623. [CrossRef] [PubMed]

78. He, D.; Li, H.; Yusuf, N.; Elmets, C.A.; Li, J.; Mountz, J.D.; Xu, H. IL-17 promotes tumor development through the induction of tumor promoting microenvironments at tumor sites and myeloid-derived suppressor cells. J. Immunol. 2010, 184, 2281-2288. [CrossRef] [PubMed]

79. Wang, L.; Yi, T.; Kortylewski, M.; Pardoll, D.M.; Zeng, D.; Yu, H. IL-17 can promote tumor growth through an IL-6-Stat3 signaling pathway. J. Exp. Med. 2009, 206, 1457-1464. [CrossRef] [PubMed]

80. Wang, L.; Yi, T.; Zhang, W.; Pardoll, D.M.; Yu, H. IL-17 enhances tumor development in carcinogen-induced skin cancer. Cancer Res. 2010, 70, 10112-10120. [CrossRef] [PubMed] 
81. Riley, T.; Sontag, E.; Chen, P.; Levine, A. Transcriptional control of human p53-regulated genes. Nat. Rev. 2008, 9, 402-412. [CrossRef] [PubMed]

82. Levine, A.J. The common mechanisms of transformation by the small DNA tumor viruses: The inactivation of tumor suppressor gene products: p53. Virology 2009, 384, 285-293. [CrossRef] [PubMed]

83. Havre, P.A.; Yuan, J.; Hedrick, L.; Cho, K.R.; Glazer, P.M. p53 inactivation by HPV16 E6 results in increased mutagenesis in human cells. Cancer Res. 1995, 55, 4420-4424. [PubMed]

84. Jiang, D.; Srinivasan, A.; Lozano, G.; Robbins, P.D. SV40 T antigen abrogates p53-mediated transcriptional activity. Oncogene 1993, 8, 2805-2812. [PubMed]

85. Quaresma, J.A.; Yoshikawa, G.T.; Koyama, R.V.; Dias, G.A.; Fujihara, S.; Fuzii, H.T. HTLV-1, immune response and autoimmunity. Viruses 2015, 8, 5. [CrossRef] [PubMed]

86. Ak, P.; Levine, A.J. p53 and NF-kB: Different strategies for responding to stress lead to a functional antagonism. FASEB J. 2010, 24, 3643-3652. [CrossRef] [PubMed]

87. Kawauchi, K.; Araki, K.; Tobiume, K.; Tanaka, N. Activated p53 induces NF-кB DNA binding but suppresses its transcriptional activation. Biochem. Biophys. Res Commun. 2008, 372, 137-141. [CrossRef] [PubMed]

88. Kawauchi, K.; Araki, K.; Tobiume, K.; Tanaka, N. p53 regulates glucose metabolism through an IKK-NF-кB pathway and inhibits cell transformation. Nat. Cell Biol. 2008, 10, 611-618. [CrossRef] [PubMed]

89. Son, D.S.; Kabir, S.M.; Dong, Y.L.; Lee, E.; Adunyah, S.E. Inhibitory effect of tumor suppressor p53 on proinflammatory chemokine expression in ovarian cancer cells by reducing proteasomal degradation of IkB. PLoS ONE 2012, 7, e51116. [CrossRef] [PubMed]

90. Lowe, J.M.; Menendez, D.; Bushel, P.R.; Shatz, M.; Kirk, E.L.; Troester, M.A.; Garantziotis, S.; Fessler, M.B.; Resnick, M.A. p53 and NF- $\mathrm{B}$ coregulate proinflammatory gene responses in human macrophages. Cancer Res. 2014, 74, 2182-2192. [CrossRef] [PubMed]

91. Rodier, F.; Campisi, J. Four faces of cellular senescence. J. Cell Biol. 2011, 192, 547-556. [CrossRef] [PubMed]

92. Davalos, A.R.; Kawahara, M.; Malhotra, G.K.; Schaum, N.; Huang, J.; Ved, U.; Beausejour, C.M.; Coppe, J.P.; Rodier, F.; Campisi, J. p53-dependent release of Alarmin HMGB1 is a central mediator of senescent phenotypes. J. Cell Biol. 2013, 201, 613-629. [CrossRef] [PubMed]

93. Bollrath, J.; Greten, F.R. IKK/NF-кB and STAT3 pathways: Central signalling hubs in inflammation-mediated tumour promotion and metastasis. EMBO Rep. 2009, 10, 1314-1319. [CrossRef] [PubMed]

94. Li, N.; Grivennikov, S.I.; Karin, M. The unholy trinity: Inflammation, cytokines, and STAT3 shape the cancer microenvironment. Cancer Cell 2011, 19, 429-431. [CrossRef] [PubMed]

95. Yu, H.; Kortylewski, M.; Pardoll, D. Crosstalk between cancer and immune cells: Role of STAT3 in the tumour microenvironment. Nat. Rev. Immunol. 2007, 7, 41-51. [CrossRef] [PubMed]

96. Yu, H.; Pardoll, D.; Jove, R. STATs in cancer inflammation and immunity: A leading role for STAT3. Nat. Rev. Cancer 2009, 9, 798-809. [CrossRef] [PubMed]

97. Niu, G.; Wright, K.L.; Ma, Y.; Wright, G.M.; Huang, M.; Irby, R.; Briggs, J.; Karras, J.; Cress, W.D.; Pardoll, D.; et al. Role of Stat3 in regulating p53 expression and function. Mol. Cell. Biol. 2005, 25, 7432-7440. [CrossRef] [PubMed]

98. Hudson, J.D.; Shoaibi, M.A.; Maestro, R.; Carnero, A.; Hannon, G.J.; Beach, D.H. A proinflammatory cytokine inhibits p53 tumor suppressor activity. J. Exp. Med. 1999, 190, 1375-1382. [CrossRef] [PubMed]

99. Bucala, R.; Donnelly, S.C. Macrophage migration inhibitory factor: A probable link between inflammation and cancer. Immunity 2007, 26, 281-285. [CrossRef] [PubMed]

100. Mitchell, R.A.; Liao, H.; Chesney, J.; Fingerle-Rowson, G.; Baugh, J.; David, J.; Bucala, R. Macrophage migration inhibitory factor (MIF) sustains macrophage proinflammatory function by inhibiting p53: Regulatory role in the innate immune response. Proc. Natl. Acad. Sci. USA 2002, 99, 345-350. [CrossRef] [PubMed]

101. Harper, J.M.; Wilkinson, J.E.; Miller, R.A. Macrophage migration inhibitory factor-knockout mice are long lived and respond to caloric restriction. FASEB J. 2010, 24, 2436-2442. [CrossRef] [PubMed]

102. Cortez, M.A.; Ivan, C.; Valdecanas, D.; Wang, X.; Peltier, H.J.; Ye, Y.; Araujo, L.; Carbone, D.P.; Shilo, K.; Giri, D.K.; et al. PDL1 Regulation by p53 via miR-34. J. Natl. Cancer Inst. 2016, 108, djv303. [CrossRef] [PubMed]

103. Aloisi, F.; Pujol-Borrell, R. Lymphoid neogenesis in chronic inflammatory diseases. Nat. Rev. Immunol. 2006, 6, 205-217. [CrossRef] [PubMed] 
104. Gajewski, T.F.; Schreiber, H.; Fu, Y.X. Innate and adaptive immune cells in the tumor microenvironment. Nat. Immunol. 2013, 14, 1014-1022. [CrossRef] [PubMed]

105. Pardoll, D. Cancer and the immune system: Basic concepts and targets for intervention. Semin. Oncol. 2015, 42, 523-538. [CrossRef] [PubMed]

106. Mellman, I.; Coukos, G.; Dranoff, G. Cancer immunotherapy comes of age. Nature 2011, 480, 480-489. [CrossRef] [PubMed]

107. Pitt, J.M.; Marabelle, A.; Eggermont, A.; Soria, J.C.; Kroemer, G.; Zitvogel, L. Targeting the tumor microenvironment: Removing obstruction to anticancer immune responses and immunotherapy. Ann. Oncol. 2016, 27, 1482-1492. [CrossRef] [PubMed]

108. Burnette, B.C.; Liang, H.; Lee, Y.; Chlewicki, L.; Khodarev, N.N.; Weichselbaum, R.R.; Fu, Y.X.; Auh, S.L. The efficacy of radiotherapy relies upon induction of type I interferon-dependent innate and adaptive immunity. Cancer Res. 2011, 71, 2488-2496. [CrossRef] [PubMed]

109. Kroemer, G.; Galluzzi, L.; Kepp, O.; Zitvogel, L. Immunogenic cell death in cancer therapy. Annu. Rev. Immunol. 2013, 31, 51-72. [CrossRef] [PubMed]

110. Zitvogel, L.; Apetoh, L.; Ghiringhelli, F.; Andre, F.; Tesniere, A.; Kroemer, G. The anticancer immune response: Indispensable for therapeutic success? J. Clin. Investig. 2008, 118, 1991-2001. [CrossRef] [PubMed]

111. Zitvogel, L.; Galluzzi, L.; Smyth, M.J.; Kroemer, G. Mechanism of action of conventional and targeted anticancer therapies: Reinstating immunosurveillance. Immunity 2013, 39, 74-88. [CrossRef] [PubMed]

112. Ma, Y.; Adjemian, S.; Mattarollo, S.R.; Yamazaki, T.; Aymeric, L.; Yang, H.; Portela Catani, J.P.; Hannani, D.; Duret, H.; Steegh, K.; et al. Anticancer chemotherapy-induced intratumoral recruitment and differentiation of antigen-presenting cells. Immunity 2013, 38, 729-741. [CrossRef] [PubMed]

113. Cekic, C.; Linden, J. Purinergic regulation of the immune system. Nat. Rev. Immunol. 2016, 16, 177-192. [CrossRef] [PubMed]

114. Shatz, M.; Menendez, D.; Resnick, M.A. The human TLR innate immune gene family is differentially influenced by DNA stress and p53 status in cancer cells. Cancer Res. 2012, 72, 3948-3957. [CrossRef] [PubMed]

115. Taura, M.; Eguma, A.; Suico, M.A.; Shuto, T.; Koga, T.; Komatsu, K.; Komune, T.; Sato, T.; Saya, H.; Li, J.D.; et al. p53 regulates Toll-like receptor 3 expression and function in human epithelial cell lines. Mol. Cell. Biol. 2008, 28, 6557-6567. [CrossRef] [PubMed]

116. Slatter, T.L.; Wilson, M.; Tang, C.; Campbell, H.G.; Ward, V.K.; Young, V.L.; Van Ly, D.; Fleming, N.I.; Braithwaite, A.W.; Baird, M.A. Antitumor cytotoxicity induced by bone-marrow-derived antigen-presenting cells is facilitated by the tumor suppressor protein p53 via regulation of IL-12. Oncoimmunology 2016, 5, e1112941. [CrossRef] [PubMed]

117. Gasser, S.; Orsulic, S.; Brown, E.J.; Raulet, D.H. The DNA damage pathway regulates innate immune system ligands of the NKG2D receptor. Nature 2005, 436, 1186-1190. [CrossRef] [PubMed]

118. Gasser, S.; Raulet, D.H. The DNA damage response arouses the immune system. Cancer Res. 2006, 66, 3959-3962. [CrossRef] [PubMed]

119. Li, H.; Lakshmikanth, T.; Garofalo, C.; Enge, M.; Spinnler, C.; Anichini, A.; Szekely, L.; Karre, K.; Carbone, E.; Selivanova, G. Pharmacological activation of p53 triggers anticancer innate immune response through induction of ULBP2. Cell Cycle 2011, 10, 3346-3358. [CrossRef] [PubMed]

120. Textor, S.; Fiegler, N.; Arnold, A.; Porgador, A.; Hofmann, T.G.; Cerwenka, A. Human NK cells are alerted to induction of p53 in cancer cells by upregulation of the NKG2D ligands ULBP1 and ULBP2. Cancer Res. 2011, 71, 5998-6009. [CrossRef] [PubMed]

121. Iannello, A.; Thompson, T.W.; Ardolino, M.; Lowe, S.W.; Raulet, D.H. p53-dependent chemokine production by senescent tumor cells supports NKG2D-dependent tumor elimination by natural killer cells. J. Exp. Med. 2013, 210, 2057-2069. [CrossRef] [PubMed]

122. Reed, J.C.; Alpers, J.D.; Nowell, P.C.; Hoover, R.G. Sequential expression of protooncogenes during lectin-stimulated mitogenesis of normal human lymphocytes. Proc. Natl. Acad. Sci. USA 1986, 83, 3982-3986. [CrossRef] [PubMed]

123. Terada, N.; Lucas, J.J.; Gelfand, E.W. Differential regulation of the tumor suppressor molecules, retinoblastoma susceptibility gene product $(\mathrm{Rb})$ and $\mathrm{p} 53$, during cell cycle progression of normal human $\mathrm{T}$ cells. J. Immunol. 1991, 147, 698-704. [PubMed] 
124. Boehme, S.A.; Lenardo, M.J. TCR-mediated death of mature T lymphocytes occurs in the absence of p53. J. Immunol. 1996, 156, 4075-4078. [PubMed]

125. Watanabe, M.; Moon, K.D.; Vacchio, M.S.; Hathcock, K.S.; Hodes, R.J. Downmodulation of tumor suppressor p53 by $\mathrm{T}$ cell receptor signaling is critical for antigen-specific $\mathrm{CD} 4^{+} \mathrm{T}$ cell responses. Immunity 2014, 40, 681-691. [CrossRef] [PubMed]

126. Cheok, C.F.; Verma, C.S.; Baselga, J.; Lane, D.P. Translating p53 into the clinic. Nat. Rev. Clin. Oncol. 2011, 8 , 25-37. [CrossRef] [PubMed]

127. Muller, P.A.; Vousden, K.H. Mutant p53 in cancer: New functions and therapeutic opportunities. Cancer Cell 2014, 25, 304-317. [CrossRef] [PubMed]

128. Khoo, K.H.; Verma, C.S.; Lane, D.P. Drugging the p53 pathway: Understanding the route to clinical efficacy. Nat. Rev. Drug Discov. 2014, 13, 217-236. [CrossRef] [PubMed]

129. Kelly, R.M.; Goren, E.M.; Taylor, P.A.; Mueller, S.N.; Stefanski, H.E.; Osborn, M.J.; Scott, H.S.; Komarova, E.A.; Gudkov, A.V.; Hollander, G.A.; et al. Short-term inhibition of p53 combined with keratinocyte growth factor improves thymic epithelial cell recovery and enhances T-cell reconstitution after murine bone marrow transplantation. Blood 2010, 115, 1088-1097. [CrossRef] [PubMed]

130. Vassilev, L.T.; Vu, B.T.; Graves, B.; Carvajal, D.; Podlaski, F.; Filipovic, Z.; Kong, N.; Kammlott, U.; Lukacs, C.; Klein, C.; et al. In vivo activation of the p53 pathway by small-molecule antagonists of MDM2. Science 2004, 303, 844-848. [CrossRef] [PubMed]

131. Saha, M.N.; Micallef, J.; Qiu, L.; Chang, H. Pharmacological activation of the p53 pathway in haematological malignancies. J. Clin. Pathol. 2010, 63, 204-209. [CrossRef] [PubMed]

132. Issaeva, N.; Bozko, P.; Enge, M.; Protopopova, M.; Verhoef, L.G.; Masucci, M.; Pramanik, A.; Selivanova, G. Small molecule RITA binds to p53, blocks p53-HDM-2 interaction and activates p53 function in tumors. Nat. Med. 2004, 10, 1321-1328. [CrossRef] [PubMed]

133. Pflaum, J.; Schlosser, S.; Muller, M. p53 family and cellular stress responses in cancer. Front. Oncol. 2014, 4, 285. [CrossRef] [PubMed]

134. Gasparini, C.; Tommasini, A.; Zauli, G. The MDM2 inhibitor Nutlin-3 modulates dendritic cell-induced T cell proliferation. Hum. Immunol. 2012, 73, 342-345. [CrossRef] [PubMed]

135. Secchiero, P.; Toffoli, B.; Melloni, E.; Agnoletto, C.; Monasta, L.; Zauli, G. The MDM2 inhibitor Nutlin-3 attenuates streptozotocin-induced diabetes mellitus and increases serum level of IL-12p40. Acta Diabetol. 2013, 50, 899-906. [CrossRef] [PubMed]

136. Bykov, V.J.; Issaeva, N.; Shilov, A.; Hultcrantz, M.; Pugacheva, E.; Chumakov, P.; Bergman, J.; Wiman, K.G.; Selivanova, G. Restoration of the tumor suppressor function to mutant p53 by a low-molecular-weight compound. Nat. Med. 2002, 8, 282-288. [CrossRef] [PubMed]

137. Stegh, A.H. Targeting the p53 signaling pathway in cancer therapy-The promises, challenges and perils. Expert Opin. Ther. Targets 2012, 16, 67-83. [CrossRef] [PubMed]

138. Formenti, S.C.; Demaria, S. Combining radiotherapy and cancer immunotherapy: A paradigm shift. J. Natl. Cancer Inst. 2013, 105, 256-265. [CrossRef] [PubMed]

139. Zitvogel, L.; Apetoh, L.; Ghiringhelli, F.; Kroemer, G. Immunological aspects of cancer chemotherapy. Nat. Rev. Immunol. 2008, 8, 59-73. [CrossRef] [PubMed]

140. Melero, I.; Arina, A.; Murillo, O.; Dubrot, J.; Alfaro, C.; Pérez-Gracia, J.L.; Bendandi, M.; Hervás-Stubbs, S. Immunogenic cell death and cross-priming are reaching the clinical immunotherapy arena. Clin. Cancer Res. 2006, 12, 2385-2389. [CrossRef] [PubMed]

(C) 2016 by the authors; licensee MDPI, Basel, Switzerland. This article is an open access article distributed under the terms and conditions of the Creative Commons Attribution (CC-BY) license (http://creativecommons.org/licenses/by/4.0/). 